\title{
OPTIMIZATION OF REGENERATION PROTOCOL OF RICE FROM EMBRYO DERIVED CALLUS
}

\author{
N. Kamal, K. M. Nasuruddin, M. S. Haque and S. Yasmin \\ Department of Biotechnology, Bangladesh Agricultural University \\ Mymensingh-2202, Bangladesh
}

\begin{abstract}
An efficient and reproducible protocol for in vitro regeneration is required to achieve high frequency transformation from transformed calli. We report here high frequency plant regeneration from mature embryonic calli of two BINA rice cultivars Binasail and Binadhan-4. Embryonic calllus initiated on MS basal medium supplemented with $2 \mathrm{mg} / 1$ 2, 4-D. Several media with different combinations of growth regulators were tried. Maximum shoot regeneration frequency $(63.33 \%)$ was observed in Binadhan- 4 on MS medium supplemented with $5 \mathrm{mg} / 1$ Kinetin $+0.5 \mathrm{mg} / 1$ NAA. Maximum root regeneration frequency $(70.00 \%)$ was observed in Binadhan- 4 on MS medium supplemented with $6 \mathrm{mg} / 1$ Kinetin $+0.5 \mathrm{mg} / 1$ NAA. Well developed plantlets were hardened and transferred to the glasshouse.
\end{abstract}

Key Words : Callus culture, Embryo, Regeneration, Rice

\section{INTRODUCTION}

Rice (Oryza sativa L.) belongs to the family Graminae. It is the staple food for more than $50 \%$ of the world's population (Aggarwal et al., 2002). Rice provides $40 \%$ calories of the world's population and nearly $80 \%$ of the required calories for the people of some Asian countries including Bangladesh (MOA, 2001). Rice consumers are increasing at the rate of 1.8 percent every year. But the rate of growth in rice production has slowed down. It is estimated that rice production has to be increased by 50 percent by 2025 (Khush and Virk, 2000). This will require increasing the yield of rice further. Conventional breeding method can not be able to breed super rice varieties. Only biotechnological approaches along with cell and tissue culture techniques can be efficiently utilized to develop super rice varieties having grain yield potential of 8-10 tons/ha with significant quality improvement. The totipotential capacity of a cell or tissue opened up several new contingencies in plant breeding programs that provided gene manipulation and selection of desirable characteristics. Plant biotechnology and in particular plant cell culture is immensely important for the improvement of the cereal crops like rice and wheat. Production of callus and its subsequent regeneration are the prime steps in crop plant to be manipulated by biotechnological means. However, embryos are easily amenable to in vitro techniques due to high totipotency of calli produced from them (Maggioni et al., 1989). The present study was conducted to observe the effect of different growth regulators at different concentrations on callus induction and plant regeneration of two BINA varieties. 


\section{MATERIALS AND METHODS}

The experiment was conducted during the period from December, 2006 to May, 2007 at the Biotechnology Laboratory, Department of Biotechnology, Bangladesh Agricultural University, Mymensingh. In the experiment, two BINA rice varieties (Binasail and Binadhan-4) were cultured on MS medium supplemented with different concentrations of growth regulators. At first, sterilized mature seeds attached to endosperm were cultured directly in MS medium supplemented with different combinations of 2, 4-D (0, $1,2,3,4 \mathrm{mg} / \mathrm{l})$ for callus initiation and callus maintenance. Different concentrations of $\mathrm{Kn}$ $(0,4,5,6,7,8,9 \mathrm{mg} / \mathrm{l})$ with a fixed NAA $(0.5 \mathrm{mg} / \mathrm{l})$ were used for shoot differentiation and root induction. The experiment was laid out in completely randomized design (CRD). The petrideshs were arranged under 5 replications. The culture petrideshs were placed in growth room, allowed to grow at $25 \pm 1^{\circ} \mathrm{C}$ and data were collected.

\section{RESULTS AND DISCUSSION}

The mature embryo explants were cultured on MS medium supplemented with 0.0, 1.0, 2.0, 3.0, $4.0 \mathrm{mg} / 1$ 2,4-D to observe the callus induction ability of two BINA (Binasail and Binadhan-4) rice varieties. Frequency of explant showing callus induction varied from 66.67 to $72.00 \%$. The highest percentage of explant showed callus induction in Binasail $(72 \%)$ and the lowest in Binadhan-4 (66.67\%) (Fig. 1A). In most of the early reports it was observed that embryogenic callus formation ability varied considerably depending on genotypes (Haque and Mansfield, 2004; Khalequzzaman, et al., 2005).

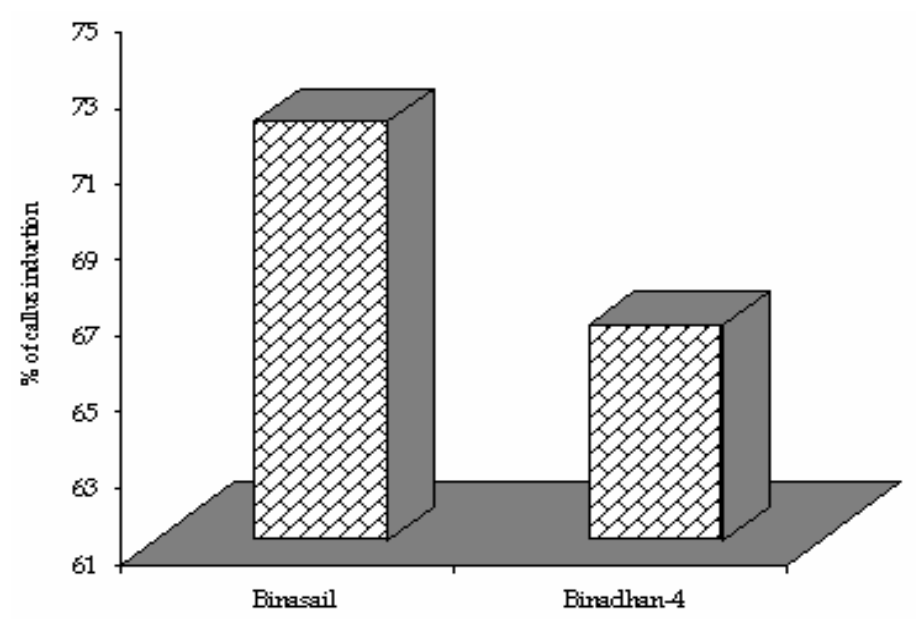

Fig. 1. Plant regeneration response of two BINA rice varieties on callus induction from mature embryos

The highest percentage of callus induction was found in $2.0 \mathrm{mg} / 12,4-\mathrm{D}(95 \%)$ and the lowest percentage of callus induction was found in $4.0 \mathrm{mg} / 12,4-\mathrm{D}(81.667 \%)$. The percentage of callus induction at $1.0 \mathrm{mg} / 12,4-\mathrm{D}(86.667 \%)$ was statistically similar to that at $3.0 \mathrm{mg} / 12,4-\mathrm{D}(83.33 \%)$ and $4 \mathrm{mg} / 12,4-\mathrm{D}(80.00 \%)$ (Fig. 2). In most of the early reports, 
it was observed that $2.0 \mathrm{mg} / 1$ 2,4-D was found to be the best for callus induction (Gao and Hung, 1999; Shankhdhar et al., 2001).

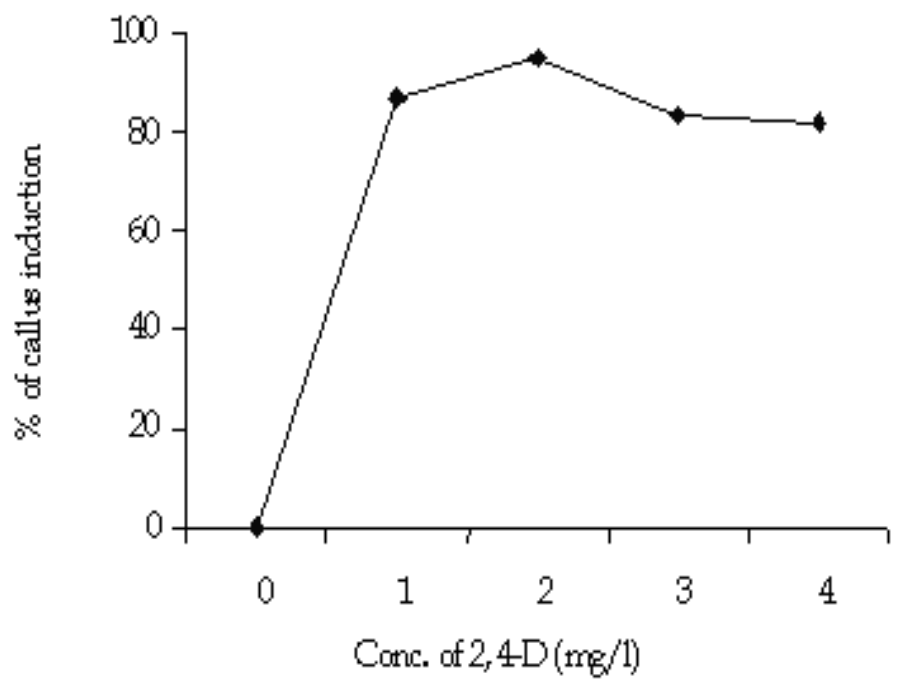

Fig. 2. Effect of different concentrations of 2,4-D in MS medium on per cent of callus induction from mature embryos

Binasail $\times 2.0 \mathrm{mg} / 1$ 2,4-D interaction was found to be the best treatment to induce the highest $(96.67 \%)$ percentage of callus. However, this combination was statistically similar to Binasail $\times 3.0 \mathrm{mg} / 1$ 2,4-D $(90.00 \%)$ and Binadhan- $4 \times 2 \mathrm{mg} / 1(93.33 \%)$. Callus induction was not observed in Binasail $\times 0 \mathrm{mg} / 1$ 2,4-D and Binadhan- $4 \times 0 \mathrm{mg} / 1$ (Table 1). It may be concluded from the present study that $2 \mathrm{mg} / 12,4-\mathrm{D}$ was proper concentration for callus induction from mature embryo in all the genotypes studied. Calli raised from different explants were subcultured at the interval of 15 days to maintain callus.

The higher number of shoots/callus was recorded in Binadhan-4 (5.714) and the lower number of shoots/callus was recorded in Binasail (3.381) (Fig. 3). Among the different combinations, $0.5 \mathrm{mg} / 1 \mathrm{NAA}$ and $5.0 \mathrm{mg} / 1$ Kinetin showed the highest number of shoots/callus (7.00). The lowest number of shoot/callus (3.833) was obtained from the combination of $0.5 \mathrm{mg} / 1 \mathrm{NAA}$ and $9 \mathrm{mg} / 1$ Kinetin (Fig. 4). Similar results were observed by Khalequzzaman et al. (2005), who reported that the different combinations and concentrations of phytohormones produced different frequencies of green shoots.

Again, Binadhan- $4 \times 6 \mathrm{mg} / 1$ Kinetin interaction was found to be the best to induce the highest number of shoot/callus (9.667). Number of shoots/callus in the interaction between Binadhan- $4 \times 7 \mathrm{mg} / 1$ Kinetin was 6.667 , that was statistically similar to Binadhan $-4 \times 5 \mathrm{mg} / 1$ Kinetin (6.667) and also to Binasail $\times 5 \mathrm{mg} / 1$ Kinetin (7.333). The 
lowest number of shoot/callus was found in Binasail $\times 9$ (2.333), which was statistically similar to Binasail $\times$ Kinetin (7.0, 6.0 and $4.0 \mathrm{mg} / \mathrm{l})$ (Table 2). It may be concluded from the present study that $6 \mathrm{mg} / 1$ Kinetin with a fixed concentration of NAA $(0.5 \mathrm{mg} / \mathrm{l})$ was the proper concentration for number of shoot/callus for Binadhan-4 genotype.

Table 1. Combined effect of different concentrations of 2,4-D on MS medium on callus induction from mature embryos of two BINA rice genotypes

\begin{tabular}{lc}
\hline \multicolumn{1}{c|}{ Variety $\times$ Treatment 2,4-D $(\mathrm{mg} / \mathrm{l})$} & \% of explant showing callus induction \\
\hline Binasail $\times 0$ & $00.00 \mathrm{~d}$ \\
Binasail $\times 1$ & $86.67 \mathrm{ab}$ \\
Binasail $\times 2$ & $96.67 \mathrm{a}$ \\
Binasail $\times 3$ & $90.00 \mathrm{a}$ \\
Binasail $\times 4$ & $86.67 \mathrm{ab}$ \\
Binadhan-4 $\times 0$ & $00.00 \mathrm{~d}$ \\
Binadhan- $4 \times 1$ & $86.67 \mathrm{ab}$ \\
Binadhan- $4 \times 2$ & $93.33 \mathrm{a}$ \\
Binadhan- $4 \times 3$ & $76.67 \mathrm{bc}$ \\
Binadhan $-4 \times 4$ & $76.67 \mathrm{~b}$ \\
\hline
\end{tabular}

Figures followed by the same letter(s) in a column do not differ, significantly at $0.05 \%$ level of significance by DMRT

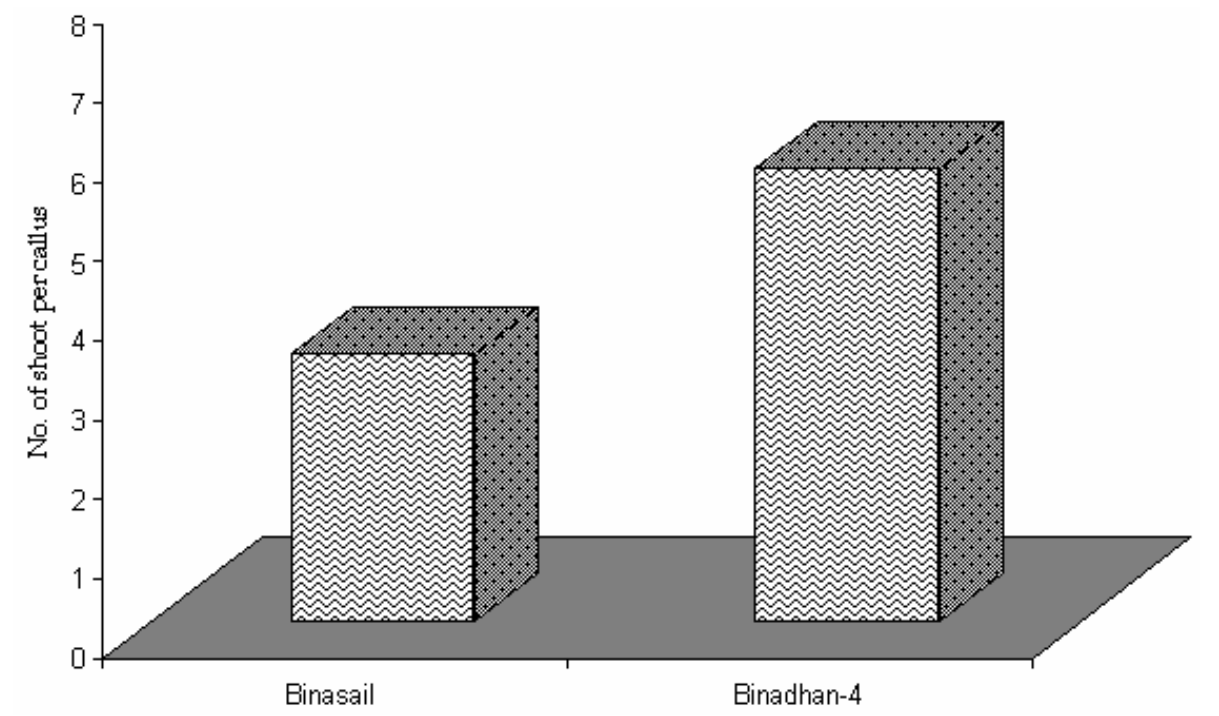

Fig. 3. Plant regeneration response of two BINA rice varieties from mature embryos on number of shoots per callus 


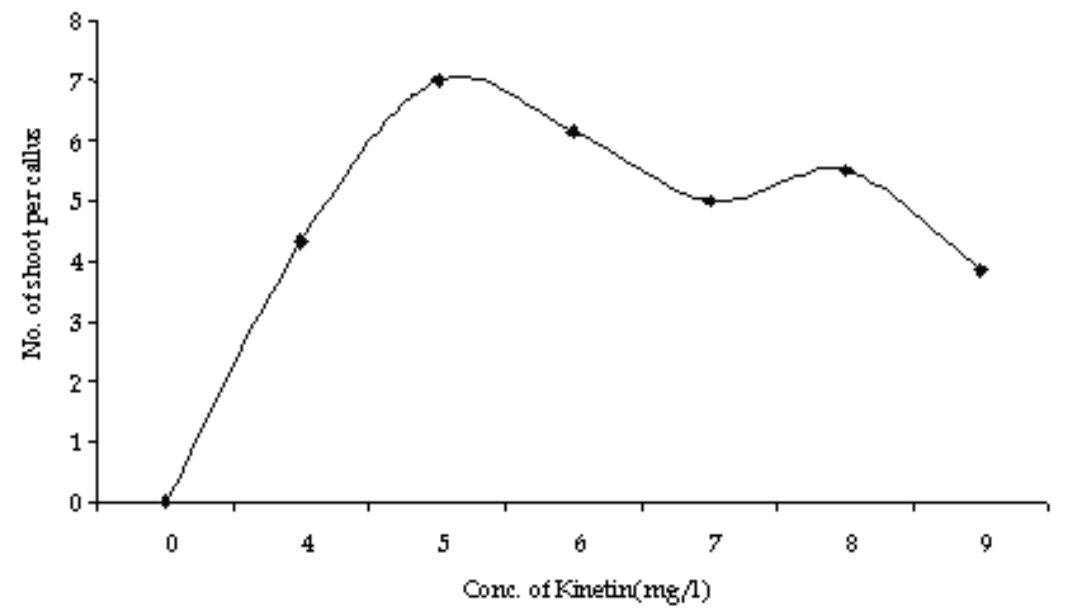

Fig. 4. Effect of different concentrations of Kinetin in the presence of $0.5 \mathrm{mg} / \mathrm{l}$ NAA on plant regeneration

Table 2. Combined effect of different concentrations of Kinetin in presence of $0.5 \mathrm{mg} / \mathrm{l}$ NAA on plant regeneration from mature embryo of rice

\begin{tabular}{c|c|c|c|c|c|c}
\hline $\begin{array}{c}\text { Variety } \times \text { Kinetin } \\
(\mathrm{mg} / \mathrm{l})\end{array}$ & $\begin{array}{c}\text { \% of Shoot } \\
\text { regeneration }\end{array}$ & $\begin{array}{c}\text { No. of shoot } \\
\text { per callus }\end{array}$ & $\begin{array}{c}\text { Shoot length } \\
(\mathrm{cm})\end{array}$ & $\begin{array}{c}\% \text { of root } \\
\text { regeneration }\end{array}$ & $\begin{array}{c}\text { No. of root } \\
\text { per explant }\end{array}$ & $\begin{array}{c}\text { root length } \\
(\mathrm{cm})\end{array}$ \\
\hline Binasail $\times 0$ & $0.000 \mathrm{f}$ & $0.000 \mathrm{f}$ & $0.000 \mathrm{f}$ & $0.000 \mathrm{f}$ & $0.000 \mathrm{~h}$ & $0.000 \mathrm{e}$ \\
Binasail $\times 4$ & $43.33 \mathrm{~d}$ & $3.333 \mathrm{e}$ & $3.533 \mathrm{c}$ & $56.67 \mathrm{c}$ & $9.333 \mathrm{~b}$ & $1.767 \mathrm{abcd}$ \\
Binasail $\times 5$ & $47.50 \mathrm{c}$ & $7.333 \mathrm{~b}$ & $3.500 \mathrm{c}$ & $63.33 \mathrm{~b}$ & $5.667 \mathrm{de}$ & $2.133 \mathrm{ab}$ \\
Binasail $\times 6$ & $56.67 \mathrm{~b}$ & $2.667 \mathrm{e}$ & $4.000 \mathrm{~b}$ & $61.67 \mathrm{~b}$ & $5.333 \mathrm{ef}$ & $2.333 \mathrm{a}$ \\
Binasail $\times 7$ & $48.33 \mathrm{c}$ & $3.333 \mathrm{e}$ & $5.000 \mathrm{a}$ & $53.33 \mathrm{c}$ & $4.333 \mathrm{fg}$ & $1.933 \mathrm{abcd}$ \\
Binasail $\times 8$ & $43.33 \mathrm{~d}$ & $4.667 \mathrm{~b}$ & $4.033 \mathrm{~b}$ & $41.67 \mathrm{~d}$ & $7.667 \mathrm{c}$ & $1.633 \mathrm{bcd}$ \\
Binasail $\times 9$ & $36.67 \mathrm{e}$ & $2.333 \mathrm{e}$ & $3.533 \mathrm{c}$ & $23.33 \mathrm{e}$ & $3.333 \mathrm{~g}$ & $1.367 \mathrm{~d}$ \\
Binadhan $-4 \times 0$ & $0.000 \mathrm{f}$ & $0.000 \mathrm{f}$ & $0.000 \mathrm{f}$ & $0.000 \mathrm{f}$ & $0.000 \mathrm{~h}$ & $0.000 \mathrm{e}$ \\
Binadhan $-4 \times 4$ & $56.67 \mathrm{~b}$ & $5.333 \mathrm{~cd}$ & $1.967 \mathrm{e}$ & $53.33 \mathrm{c}$ & $6.667 \mathrm{~cd}$ & $1.633 \mathrm{bcd}$ \\
Binadhan $-4 \times 5$ & $63.33 \mathrm{a}$ & $6.667 \mathrm{~b}$ & $2.033 \mathrm{e}$ & $61.67 \mathrm{~b}$ & $13.333 \mathrm{a}$ & $1.933 \mathrm{abcd}$ \\
Binadhan $-4 \times 6$ & $56.67 \mathrm{~b}$ & $9.667 \mathrm{a}$ & $2.567 \mathrm{~d}$ & $70.00 \mathrm{a}$ & $7.333 \mathrm{c}$ & $2.267 \mathrm{a}$ \\
Binadhan $-4 \times 7$ & $48.33 \mathrm{c}$ & $6.667 \mathrm{~b}$ & $2.033 \mathrm{e}$ & $63.33 \mathrm{~b}$ & $5.667 \mathrm{de}$ & $1.967 \mathrm{abc}$ \\
Binadhan $-4 \times 8$ & $47.50 \mathrm{c}$ & $6.333 \mathrm{bc}$ & $3.567 \mathrm{c}$ & $53.33 \mathrm{c}$ & $7.333 \mathrm{c}$ & $1.667 \mathrm{bcd}$ \\
Binadhan $-4 \times 9$ & $36.67 \mathrm{e}$ & $5.333 \mathrm{~cd}$ & $2.533 \mathrm{~d}$ & $28.33 \mathrm{e}$ & $3.333 \mathrm{~g}$ & $1.433 \mathrm{~cd}$ \\
\hline
\end{tabular}

Figures followed by the same letter(s) in a column do not differ, significantly at $0.05 \%$ level of significance by DMRT

The highest shoot length was recorded in Binasail $(3.371 \mathrm{~cm})$ and the lowest shoot length was found in Binadhan-4 $(2.10 \mathrm{~cm})$ (Fig. 5). Again, the highest shoot length $(3.8 \mathrm{~cm})$ was 
found in $0.5 \mathrm{mg} / 1 \mathrm{NAA}$ and $8.0 \mathrm{mg} / 1$ Kinetin concentration. The lowest shoot length $(2.75 \mathrm{~cm})$ was recorded in $0.5 \mathrm{mg} / 1 \mathrm{NAA}$ and $4.0 \mathrm{mg} / 1$ Kinetin (Fig. 6).

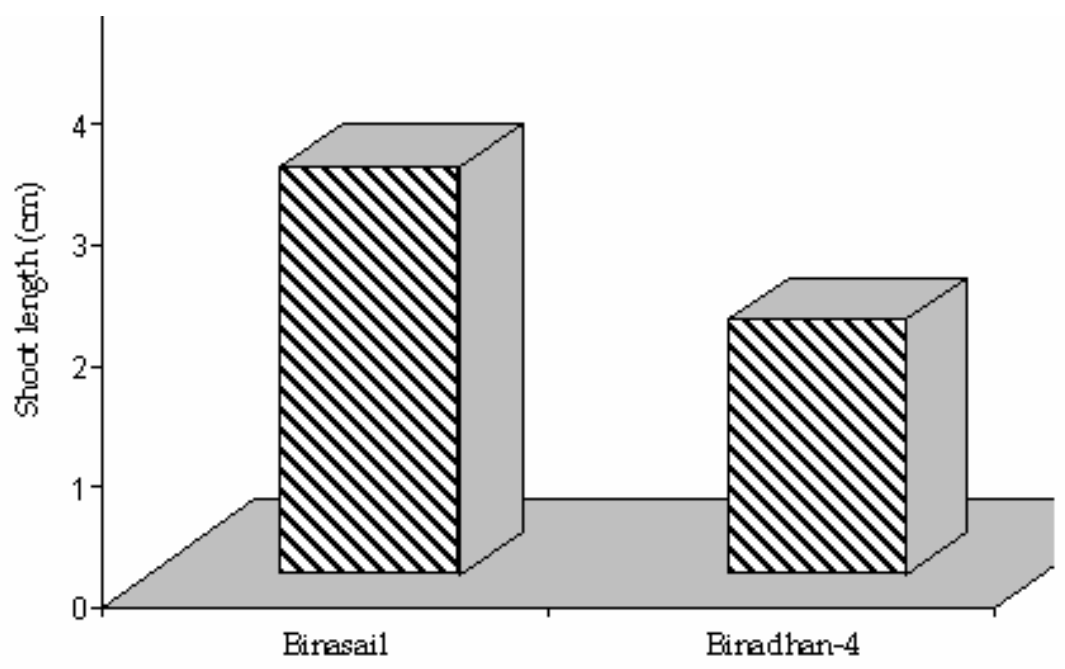

Fig. 5. Shoot elongation response of two BINA rice varieties from mature embryos

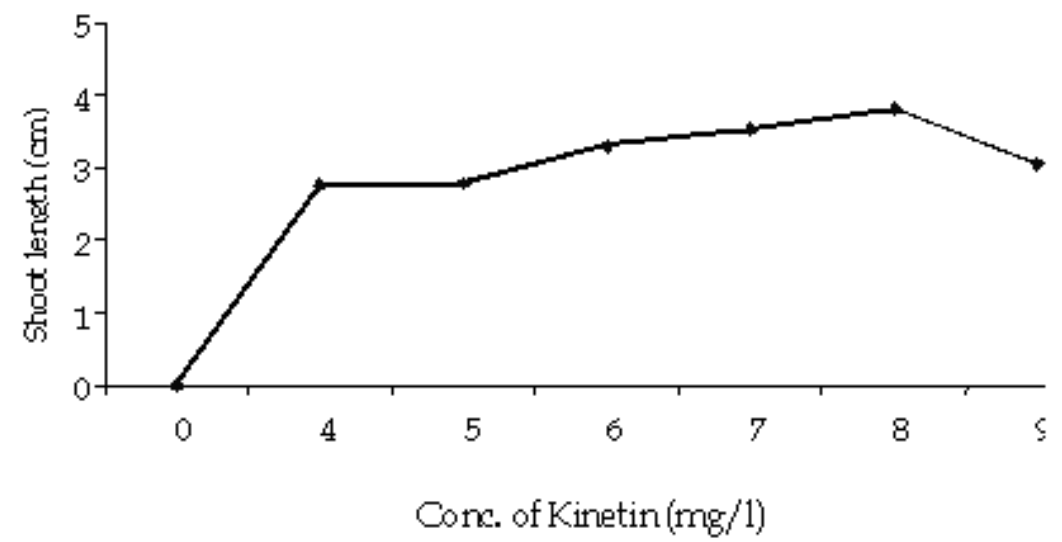

Fig. 6. Effect of different concentrations of Kinetin in the presence of $0.5 \mathrm{mg} / \mathrm{l}$ NAA on shoot length

Binasail $\times 7 \mathrm{mg} / 1$ Kinetin interaction $(5.00 \mathrm{~cm})$ was found to be the highest shoot length. The lowest length of shoot was recorded at Binadhan $-4 \times 7 \mathrm{mg} / 1(2.033 \mathrm{~cm})$, Binadhan- $4 \times$ $5 \mathrm{mg} / 1$ (2.033) and Binadhan $-4 \times 4 \mathrm{mg} / 1(1.967 \mathrm{~cm})$ Kinetin (Table 2).

The highest percentage of root induction was recorded in Binadhan-4 (6.238) and the lowest percentage of root induction was in Binasail (5.095) (Fig. 7). The highest number of root/explant was recorded at $5 \mathrm{mg} / 1$ Kinetin (9.5) and the lowest number of 
root/explant was found at $9 \mathrm{mg} / 1$ Kinetin (3.333) (Fig. 8). The highest number of roots/explant was found in Binadhan $-4 \times 5 \mathrm{mg} / 1$ Kinetin (13.333). The lowest number of root/explant was found at Binasail $\times 9 \mathrm{mg} / 1$ Kinetin (3.333) and Binadhan $-4 \times 9 \mathrm{mg} / 1$ Kinetin (3.333). Binasail showed the highest $(1.595 \mathrm{~cm})$ and Binadhan 4 showed the lowest root length $(1.557 \mathrm{~cm})$ (Fig. 9). The highest length of root $(2.3 \mathrm{~cm})$ was recorded at $6 \mathrm{mg} / \mathrm{l} \mathrm{Kinetin} \mathrm{level} \mathrm{and} \mathrm{the} \mathrm{lowest} \mathrm{length} \mathrm{of} \mathrm{root}(1.4 \mathrm{~cm})$ was recorded at $9 \mathrm{mg} / 1$ Kinetin level (Fig. 10). Binasail $\times 6 \mathrm{mg} / 1$ Kinetin interaction $(2.333 \mathrm{~cm})$ was found to be the highest, which statistically similar to that of in Binadhan- $4 \times 6 \mathrm{mg} / 1$ Kinetin interaction $(2.267 \mathrm{~cm})$. The lowest length of root was recorded at Binasail $\times 9 \mathrm{mg} / 1$ Kinetin interaction $(1.367 \mathrm{~cm})$.

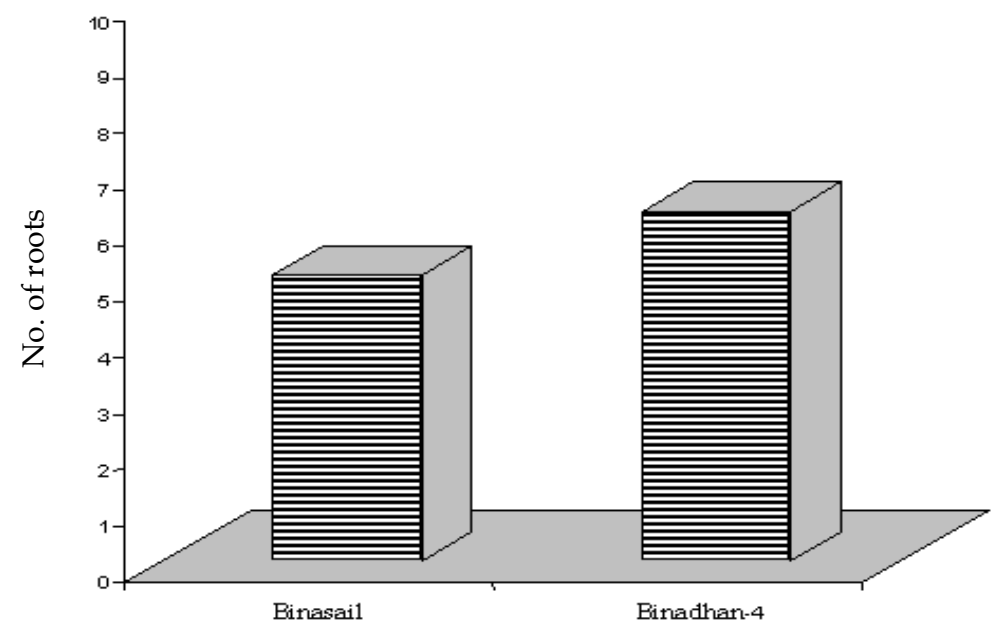

Fig. 7. Rooting response of two BINA rice varieties from mature

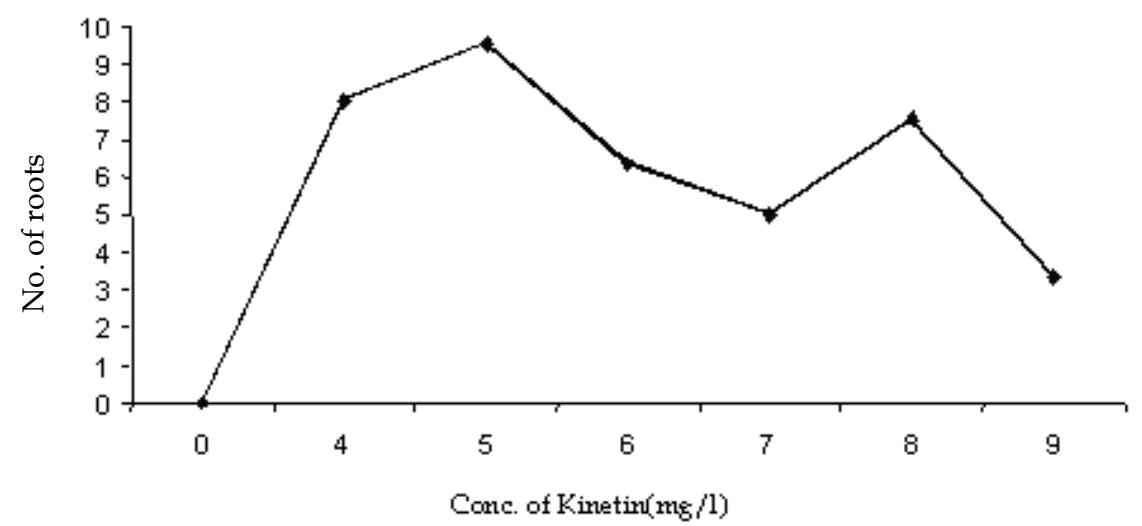

Fig. 8. Effect of different concentrations of Kinetin in the presence of $0.5 \mathrm{mg} / 1$ NAA on number of roots

The results from the present study suggest that, $2 \mathrm{mg} / 12,4-\mathrm{D}$ was the best concentration in Binasail for callus induction and callus maintenance. Binadhan $-4 \times 5 \mathrm{mg} / 1$ Kinetin 
showed the best shoot regeneration and the highest percentage of root induction was found in Binadhan $-4 \times 6 \mathrm{mg} / 1$ kinetin.

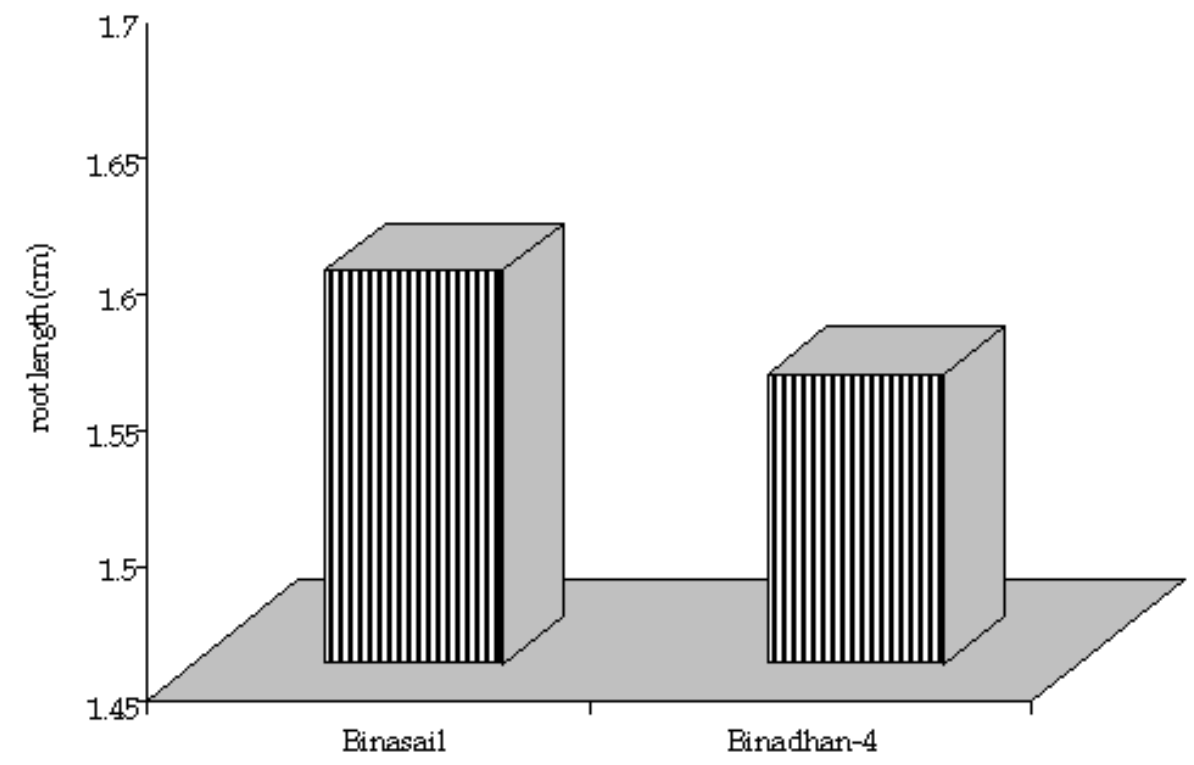

Fig. 9. Plant regeneration response of two BINA rice varieties from mature embryos on root length

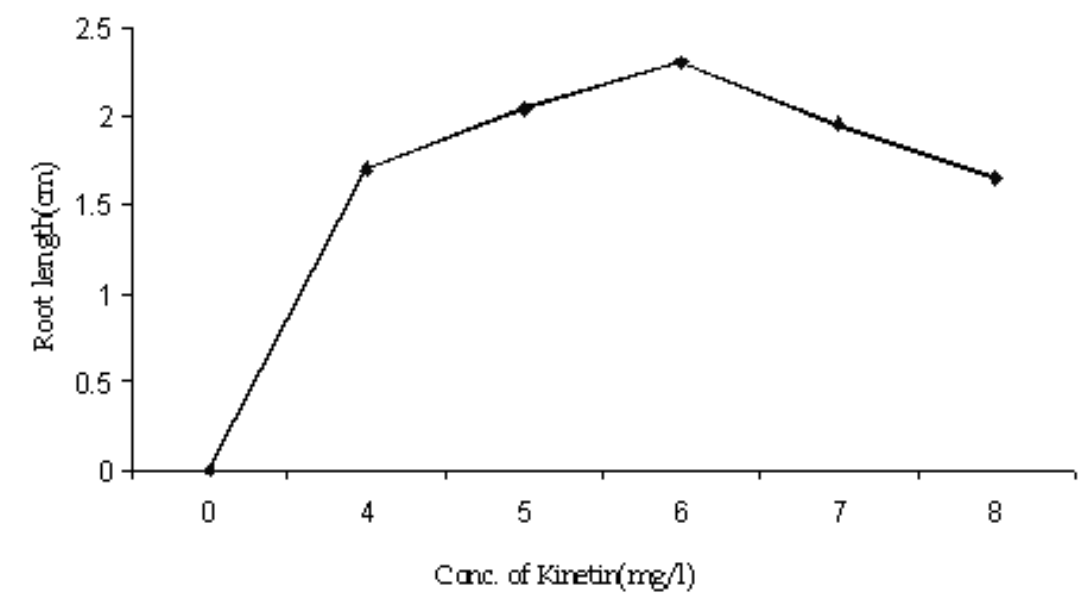

Fig. 10. Effect of different concentrations of Kinetin in the presence of $0.5 \mathrm{mg} / 1$ NAA on root length 


\section{REFERENCES}

Aggarwal, R. W., Shenoy, V. V. and Ramadevi, J. 2002. Molecular characterization of some Indian basmati and other elite rice genotypes using fluorescent AFLP. Theor. Appl. Genet., 105 : 887-890.

Haque, M. E. and Mansfield, J. W. 2004. Effect of genotype and explant age on callus induction and subsequent plant regeneration from root derived callus of indica rice genotypes. Plant Cell Tissue Org. Cult., 78 (3) : 217-223.

Khalequzzaman, M., Haque, N., Haque, E. and Aditya, T. L. 2005. Regeneration Efficiency and Genotypic Effect of 15 indica type Bangladeshi Rice (Oryza sativa L.). Plant Tissue Cult., 15(1) : 33-42.

Khush, G. S. and Virk, P. S. 2000. Rice Breeding: Achievement and future strategies. Crop Improv., 27: 115-144.

Maggioni, L., Lusrdi, M. C. and Lupotto, E. 1989. Effect of culture condition callus induction and plant regeneration from mature and immature embryos of rice varieties (Oryza sativa L.). J. Genet. Breed., 43 : 99-106.

MOA (Ministry of Agriculture) 2001. Bangladesh Food and Tree, World Food Summit. 13-17 Nov. Rome, Italy. 7. 